\title{
ELEMENTAL COMPOSITION OF A COMPOSITE OF SAMPLES HTF-E-03-162 TO 164 FROM TANK 51H TO EVALUATE ACCEPTABILITY OF THE SLUDGE FOR TRANSFER TO TANK 40H AND PROCESSING IN THE DWPF (U)
}

N. E. Bibler

January 2004

Immoblization Technology Section Savannah River Technology Center Savannah River Technology Center Aiken, SC 29808

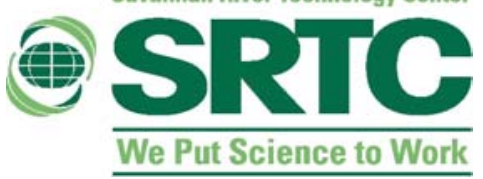


This document was prepared in conjunction with work accomplished under Contract No. DE-AC09-96SR18500 with the U. S. Department of Energy.

\section{DISCLAIMER}

This report was prepared as an account of work sponsored by an agency of the United States Government. Neither the United States Government nor any agency thereof, nor any of their employees, makes any warranty, express or implied, or assumes any legal liability or responsibility for the accuracy, completeness, or usefulness of any information, apparatus, product or process disclosed, or represents that its use would not infringe privately owned rights. Reference herein to any specific commercial product, process or service by trade name, trademark, manufacturer, or otherwise does not necessarily constitute or imply its endorsement, recommendation, or favoring by the United States Government or any agency thereof. The views and opinions of authors expressed herein do not necessarily state or reflect those of the United States Government or any agency thereof.

This report has been reproduced directly from the best available copy.

Available for sale to the public, in paper, from: U.S. Department of Commerce, National Technical Information Service, 5285 Port Royal Road, Springfield, VA 22161, phone: (800) 553-6847, fax: (703) 605-6900

email: orders@ntis.fedworld.gov

online ordering: http://www.ntis.gov/help/index.asp

Available electronically at http://www.osti.gov/bridge

Available for a processing fee to U.S. Department of Energy and its contractors, in paper, from: U.S. Department of Energy, Office of Scientific and Technical Information, P.O. Box 62, Oak Ridge, TN 37831-0062,

phone: (865)576-8401,

fax: (865)576-5728

email: $\underline{\text { reports@ adonis.osti.gov }}$ 
Key Words:

Sludge Composition

Sample Analysis

Retention:

Permanent

\section{ELEMENTAL COMPOSITION OF A COMPOSITE OF SAMPLES HTF-E-03-162 TO 164 FROM TANK 51H TO EVALUATE ACCEPTABILITY OF THE SLUDGE FOR TRANSFER TO TANK 40H AND PROCESSING IN THE DWPF (U)}

N. E. Bibler

January 2004 


\section{EXECUTIVE SUMMARY}

Three dip samples of suspended sludge slurry were obtained from Tank $51 \mathrm{H}$ and sent to the Savannah River Technology Center for analysis. The composite of these samples is intended as a confirmatory sample to evaluate the acceptability of the Tank $51 \mathrm{H}$ sludge slurry for transfer to Tank $40 \mathrm{H}$ and for eventual processing in the Defense Waste Processing Facility. This report presents results of analyses requested by the Defense Waste Processing Facility for this evaluation. These analyses included the measurement of the concentrations of twenty two elements in the sludge slurry and the determination of the weight percent calcined solids of the slurry. 


\section{TABLE OF CONTENTS}

EXECUTIVE SUMMARY iv

LIST OF TABLES $\quad$ V

LIST OF ACRONYMS $\quad$ V

1.0 INTRODUCTION 1

2.0 SAMPLE RECEIVING AND COMPOSITING 1

3.1 RESULTS OF ELEMENTAL ANALYSES 1

3.2 RESULTS FOR CALCINED SOLIDS 3

4.0 REFERENCES 4

\section{LIST OF TABLES}

Table 3-1 Concentrations of Elements Requested by DWPF in the Tank 51H Confirmatory

Sample Presented in Units of Weight Percent of Total Dried Solids

\section{LIST OF ACRONYMS}

\% RSD Percent Relative Standard Deviations

AA Atomic Adsorption

ADS Analytical Development Section

DWPF Defense Waste Processing Facility

ICP-ES Inductively Coupled Plasma - Emission Spectroscopy

SRTC Savannah River Technology Center 


\subsection{INTRODUCTION}

Three dip samples of suspended sludge slurry were obtained from Tank $51 \mathrm{H}$ and sent to the Savannah River Technology Center (SRTC) for analysis. The analyses requested included those required for Extended Sludge Processing washing and corrosion controls [1] and also analyses requested by the Defense Waste Processing Facility (DWPF) to evaluate the acceptability of the transfer of the sludge slurry to Tank $40 \mathrm{H}$ and eventual processing in the DWPF [2]. The washing controls require the measurement of the sodium concentration, along with the density, and weight percent solids of the sample. The corrosion control analyses require determination of the nitrate, nitrite, and free hydroxide concentrations in the supernate. Results of these analyses have been reported.[3]. This report presents results of the analyses requested by the DWPF. These analyses included the measurement of the concentrations of twenty two elements in the sludge slurry and the determination of the weight percent calcined solids of the sludge slurry.

\subsection{SAMPLE RECEIVING AND COMPOSITING}

The three dip samples ( $\sim 80 \mathrm{~mL}$ each) of suspended sludge were taken from Tank $51 \mathrm{H}$ in December, 2003, and sent to SRTC. These samples were labeled HTF-E-03-162, HTF-E-03163, and HTF-E-03-164. The samples were received at SRTC and placed in the Shielded Cells. The samples were mixed thoroughly and composited into a single sample for the analyses. After the samples had been composited, a portion of the slurry was used to rinse any remaining solids from the three dip sample vials into the compositing vessel. During compositing and rinsing, the sludge slurry appeared no different from previous samples of sludge slurries received by SRTC for characterization. There were no lumps in the samples and they flowed freely while pouring. The final volume of the composite sample was $\sim 250 \mathrm{~mL}$ and weighed 290.2 grams. From this composite, aliquots were then taken for characterization and analysis.

\subsection{RESULTS AND DISCUSSION}

\subsection{RESULTS OF ELEMENTAL ANALYSES}

Provided below in Table 3.1 are the results of the analyses of the Tank 51 sludge slurry sample for the 22 requested elements. To determine elemental concentrations, eight aliquots of the mixed sludge slurry sample were taken and dried overnight in a drying oven at $115^{\circ} \mathrm{C}$. Four dried aliquots were dissolved by the Analytical Development Section (ADS) approved procedure for dissolving sludge by Aqua Regia [4]. Four were also dissolved by the ADS approved procedure for dissolving sludge by Sodium Peroxide/Sodium Hydroxide Fusion [5]. Triplicate samples of an appropriate standard glass were also dissolved with each procedure to check if the dissolutions were complete and if the analytical methods performed correctly. After performing the dissolution methods on the dried solids (nominally 0.25 grams), the solutions were diluted to exactly $100 \mathrm{~mL}$. Aliquots of the dilutions were removed from the Shielded Cells Facility and were sent to ADS Sample Receiving for analyses to be performed by ADS. The ADS methods included Inductively Coupled Plasma-Emission Spectroscopy (ICP-ES) and Atomic Adsorption (AA). Average concentrations measured in the Tank 51H sludge samples are presented in Table 3-1. Results for the dissolutions of the standard glass for each average reported were in good agreement with the known values indicating that the dissolution methods were complete and that the analyses performed correctly. Standard solutions were also analyzed with the dissolved samples and indicated that the analyses were correct. A blank sample for each dissolution method was prepared. 
Analytical results of the blanks for each reported element, indicated that their respective concentrations in the blank were negligible compared to concentrations measured in the solutions of dissolved dried sludge. Table 3.1 presents the results for the elements requested by the DWPF. Table 3.1 also presents the standard deviations and the percent relative standard deviations for the averages reported. Averages of either four or eight samples of dried sludge are reported

Table 3-1 Concentrations of Elements Requested by DWPF in the Tank 51H Confirmatory Sample Presented in Units of Weight Percent of Total Dried Solids. Standard Deviations and Percent Relative Standard Deviations (\%RSD) are also presented.

\begin{tabular}{|c|c|c|c|c|c|}
\hline Element & $\begin{array}{c}\text { Wt\% of Total } \\
\text { Solids }\end{array}$ & $\begin{array}{c}\text { Std. Dev. and } \\
\% \text { RSD }\end{array}$ & Element & $\begin{array}{c}\text { Wt\% of Total } \\
\text { Solids }\end{array}$ & $\begin{array}{c}\text { Std. Dev. and } \\
\% \text { RSD }\end{array}$ \\
\hline $\mathrm{Al}^{\mathrm{a}}$ & $6.27 \mathrm{E}+00$ & $\begin{array}{l}2.4 \mathrm{E}-01 \\
4.0 \mathrm{E}+00\end{array}$ & $\mathrm{Li}^{\mathrm{c}}$ & $2.3 \mathrm{E}-02$ & $\begin{array}{c}1.0 \mathrm{E}-03 \\
4.0 \mathrm{E}+00\end{array}$ \\
\hline $\mathrm{B}^{\mathrm{b}}$ & $2.4 \mathrm{E}-02$ & $\begin{array}{r}7.0 \mathrm{E}-03 \\
2.9 \mathrm{E}+01 \\
\end{array}$ & $\mathrm{Mg}^{\mathrm{b}}$ & $1.57 \mathrm{E}+00$ & $\begin{array}{l}9.1 \mathrm{E}-02, \\
5.8 \mathrm{E}+00\end{array}$ \\
\hline $\mathrm{Ba}^{\mathrm{b}}$ & $6.1 \mathrm{E}-02$ & $\begin{array}{l}5.0 \mathrm{E}-03, \\
8.1 \mathrm{E}+00\end{array}$ & $\mathrm{Mn}^{\mathrm{b}}$ & $4.41 \mathrm{E}+00$ & $\begin{array}{l}1.9 \mathrm{E}-01, \\
4.4 \mathrm{E}+00\end{array}$ \\
\hline $\mathrm{Ca}^{\mathrm{b}}$ & $1.30 \mathrm{E}+00$ & $\begin{array}{l}7.7 \mathrm{E}-02, \\
6.0 \mathrm{E}+00\end{array}$ & $\mathrm{Na}^{\mathrm{c}}$ & $1.25 \mathrm{E}+01$ & $\begin{array}{l}1.9 \mathrm{E}-01, \\
1.5 \mathrm{E}+00\end{array}$ \\
\hline $\mathrm{Cd}^{\mathrm{b}}$ & $2.32 \mathrm{E}-01$ & $\begin{array}{l}1.0 \mathrm{E}-02, \\
4.2 \mathrm{E}+00 \\
\end{array}$ & $\mathrm{Ni}^{\mathrm{b}}$ & $1.03 \mathrm{E}+00$ & $\begin{array}{l}4.8 \mathrm{E}-02, \\
4.7 \mathrm{E}+00 \\
\end{array}$ \\
\hline $\mathrm{Cr}^{\mathrm{b}}$ & $8.6 \mathrm{E}-02$ & $\begin{array}{l}9.0 \mathrm{E}-03, \\
1.0 \mathrm{E}+01\end{array}$ & $\mathrm{~S}^{\mathrm{c}}$ & $2.50 \mathrm{E}-01$ & $\begin{array}{l}2.3 \mathrm{E}-03, \\
9.3 \mathrm{E}-01\end{array}$ \\
\hline $\mathrm{Cu}^{\mathrm{b}}$ & $2.6 \mathrm{E}-02$ & $\begin{array}{l}2.0 \mathrm{E}-03 \\
8.3 \mathrm{E}+00 \\
\end{array}$ & $\mathrm{Si}^{\mathrm{a}}$ & $1.31 \mathrm{E}+00$ & $\begin{array}{l}6.2 \mathrm{E}-02, \\
4.7 \mathrm{E}+00\end{array}$ \\
\hline $\mathrm{Fe}^{\mathrm{b}}$ & $1.51 \mathrm{E}+01$ & $\begin{array}{l}7.9 \mathrm{E}-01, \\
5.2 \mathrm{E}+00\end{array}$ & $\mathrm{Sr}^{\mathrm{a}}$ & $3.77 \mathrm{E}-01$ & $\begin{array}{l}1.1 \mathrm{E}-02, \\
2.9 \mathrm{E}+00\end{array}$ \\
\hline $\mathrm{Gd}^{\mathrm{b}}$ & $6.0 \mathrm{E}-02$ & $\begin{array}{l}8.0 \mathrm{E}-03, \\
1.4 \mathrm{E}+01\end{array}$ & $\mathrm{Ti}^{\mathrm{b}}$ & $2.0 \mathrm{E}-02$ & $\begin{array}{l}1.0 \mathrm{E}-03, \\
6.8 \mathrm{E}+00\end{array}$ \\
\hline $\mathrm{Hg}^{\mathrm{d}}$ & $1.41 \mathrm{E}-01$ & $\begin{array}{l}1.0 \mathrm{E}-03, \\
1.0 \mathrm{E}+00\end{array}$ & $\mathrm{U}^{\mathrm{b}}$ & $6.55 \mathrm{E}+00$ & $\begin{array}{l}3.1 \mathrm{E}-01, \\
4.7 \mathrm{E}+00\end{array}$ \\
\hline $\mathrm{K}^{\mathrm{d}}$ & $6.9 \mathrm{E}-02$ & $\begin{array}{l}1.0 \mathrm{E}-03, \\
8.2 \mathrm{E}-01\end{array}$ & $\mathrm{Zr}^{\mathrm{c}}$ & $1.20 \mathrm{E}-02$ & $\begin{array}{l}4.0 \mathrm{E}-03, \\
3.2 \mathrm{E}+01\end{array}$ \\
\hline
\end{tabular}

${ }^{\mathrm{a}}$ Average of four measurements by ICP-ES (from peroxide fusion digestions).

${ }^{b}$ Average of eight measurements by ICP-ES (four aqua regia digestions and four peroxide fusion digestions).

${ }^{c}$ Average of four measurements by ICP-ES (from aqua regia digestions).

${ }^{\mathrm{d}}$ Average of four measurements by AA (from aqua regia digestions). 


\subsection{RESULTS FOR CALCINED SOLIDS}

Triplicate measurements of the calcined solids were completed in the Shielded Cells Facility for the sludge slurry. Mixed portions of a sample of sludge slurry were pipetted into each of three pre-weighed alumina crucibles. The crucibles were weighed and then dried overnight at $115^{\circ} \mathrm{C}$ in a drying oven to avoid any loss of the material during the calcining process. The samples were removed from the drying oven and allowed to cool for $\sim 5$ minutes before they were weighed. The samples were then placed into a muffle furnace and heated to $1050^{\circ} \mathrm{C}$. The samples were held at $1050^{\circ} \mathrm{C}$ for approximately one hour. The muffle furnace was then turned off and the samples were allowed to cool inside of the muffle furnace. The samples were then removed from the muffle furnace, weighed, and the calcined solids were calculated. To check whether the calcinations were complete, the crucibles were returned to the furnace and heated at $1050^{\circ} \mathrm{C}$ for an additional hour. They were then cooled and weighed again. There was no change in weight indicating that calcinations were indeed complete. The average of the triplicate results for the weight percent calcine solids for the sludge slurry is $20.0 \%$ with a percent relative standard deviation of $0.03 \%$. As expected, the weight percent calcined solids was less than the weight percent dried solids (25.9\% reported in Reference 3.) 


\subsection{REFERENCES}

1. Davis, P, Technical Task Request SB3 Confirmation Sample Analysis, HLW/TTR-2004-015, Rev.0, September 15, 2003.

2. Rios-Armstrong, M. A., Technical Task Request SB3 Tank 51 Confirmatory Sample Analysis, HLW/DWPF/TTR-03-0021, December, 2003.

3. Hay, M. S., Characterization of a Composite of Samples HTF-E-03-162, 163, and 164 from Tank $51 H$ (U), WSRC-TR-2004-00038, REV.0, January, 2003.

4. Coleman, C. J., Aqua Regia Dissolution of Sludge for Elemental Analysis (U), ADS Procedure, ADS-2226, Rev. 5, September 30, 1998.

5. Coleman, C. J., Alkali Fusion Dissolutions of Sludge and Glass for Elemental and Anion Analysis (U), ADS Procedure, ADS-2502, Rev. 5, November 1, 2002. 